\title{
Microstructure and Mechanical Properties of Al/Steel Butt Joint by Hybrid CMT Welding with External Axial Magnetic Field
}

\author{
Kexin Kang ${ }^{1}$, Yibo Liu ${ }^{1,2, *}$, Junzhao Li ${ }^{1,2}$, Chao Liu ${ }^{1}$, Zuyang Zhen ${ }^{1}$, Yaxin Wang ${ }^{1}$ \\ and Qingjie Sun ${ }^{1,2}$ \\ 1 Shandong Provincial Key Laboratory of Special Welding Technology, Harbin Institute of Technology at \\ Weihai, No.2 West Wenhua Road, Weihai 264209, China; kangkx_hit@163.com (K.K.); \\ ljzhao_hit@163.com (J.L.); 17863109157@163.com (C.L.); zhenzuyang@163.com (Z.Z.); \\ wangyaxin1995@163.com (Y.W.); qjsun@hit.edu.cn (Q.S.) \\ 2 State Key Laboratory of Advanced Welding and Joining, Harbin Institute of Technology, \\ No.92 West Dazhi Street, Harbin 150001, China \\ * Correspondence: ybliu0701@hit.edu.cn; Tel./Fax: +86-0631-5677156
}

Received: 13 July 2020; Accepted: 11 August 2020; Published: 14 August 2020

\begin{abstract}
The 6061 aluminum alloy and 304 stainless steel were welded by hybrid cold metal transfer (CMT) welding with external axial magnetic field. The effects of magnetic intensity and frequency on joint microstructure and mechanical properties were studied. It was found that the magnetic field can promote the spreading of aluminum weld metal on the steel surface and thus increase the bonding area of $\mathrm{Al} /$ steel butt joint. The welding process stability improved, while the wetting behavior worsened with the introduction of alternating frequencies. The thickness of the intermetallic compound (IMC) layer at $\mathrm{Al} /$ steel interface was reduced to $3 \mu \mathrm{m}$ with the coil current of $2 \mathrm{~A}$. The application of the magnetic field promoted the aggregation of $\mathrm{Si}$ atoms at the interface and inhibited the formation of brittle $(\mathrm{Al}, \mathrm{Si})_{13} \mathrm{Fe}_{4}$ phase. The fracture paths were transformed from $(\mathrm{Al}, \mathrm{Si})_{13} \mathrm{Fe}_{4}$ layer to $\mathrm{Al}_{8} \mathrm{Fe}_{2} \mathrm{Si}$ layer with the application of the magnetic field. The maximum tensile strength reached 130.2 MPa, an increase of $61.6 \%$ in comparison to the normal CMT process.
\end{abstract}

Keywords: axial magnetic field; aluminum and steel; CMT welding; interfacial microstructure; tensile strength

\section{Introduction}

In order to save fossil energy and reduce greenhouse gas emissions, the lightweight automobile has become one of the development directions of automobile industry. Due to its high specific strength, good corrosion resistance, and low cost, aluminum and its alloys have great potential to replace the conventional steel component. As a result, the sound aluminum and steel welded joint has gained extensive attention [1]. However, distinct differences in thermal physical properties and the formations of brittle intermetallic compounds (IMCs) at the bonding interface are obstacles to achieve effective connection [2]. Therefore, many welding methods have been applied to realize dissimilar metals welding of $\mathrm{Al}$ and steel [3]. The key of $\mathrm{Al} /$ steel welding is to control the IMC layer thickness at the interface. Chen et al. [4] considered that only when the thickness of IMC layer is less than $10 \mu \mathrm{m}$ will the joints achieve good properties. Cao et al. [5] analyzed the relationship between joint strength and IMCs and found that the tensile strength of the joint decreased when the IMC layer was thicker than $5 \mu \mathrm{m}$.

At present, two main methods are used to control the growth of the IMC layer. One is to add alloy elements at the interface. Zn addition is known to change the IMC phase, which can 
decrease the brittleness of the interfacial region and consequently increase the fracture load [6-8]. He et al. [9] found that the addition of Ni to 5A06 aluminum alloy and SUS321 stainless steel welding can significantly decrease the IMC layer thickness and improve the mechanical properties of the butt joints. Si is considered to be able to decelerate growth and reduce the brittleness of the IMC layer, thereby improving the joint mechanical properties [10-13]. Xia et al. [14] joined 6061-T6 aluminum alloy and DP590 steel by the laser welding-brazing process with pure Al, AlSi5, and AlSi12 filler metals. They found that Si content affected the reaction mechanism and led to different IMC components. The joint produced with the AlSi5 filler metal had the highest tensile strength and the largest fracture displacement. Moreover, it is important to control the heat input of $\mathrm{Al} / \mathrm{steel}$ welding process. It is acknowledged that lower heat input is beneficial to the inhibition of IMC growth and the improvement of joint strength $[15,16]$. Shiran et al. [17] investigated the effect of heat treatment on the IMCs of the stainless steel 321-aluminum 1230 explosive-welding interface. The results indicated that the IMC layer thickness increased and the joint strength decreased with the increase of the duration and temperature of heat treatment. Li et al. [18] found that with the increase of heat input, the thickness and the brittleness of the IMC layer increased accordingly. However, low heat input tended to result in terrible wettability of welding seam due to the bad fluidity of the molten pool with a low temperature $[19,20]$.

Nevertheless, the wetting behavior was considered to have a strong influence on the mechanical strength of the assembly [21]. Sun et al. [22] joined Al/steel with ER4043 filler metal and found that the tensile strength of the $\mathrm{Al} / \mathrm{steel}$ butt joint is not only related to the thickness of the IMC layer, but also the bonding area. Therefore, improving the wettability of the joint and reducing the thickness of the IMC layer are two avenues to obtain the high tensile strength of $\mathrm{Al} /$ steel butt joint. As an auxiliary means of arc welding, the magnetic field has played an important role in the welding process with no solder assisted [23]. Yan et al. [24] discovered that the magnetic field can control the formation of IMCs at the interface of $\mathrm{Al} /$ steel and inhibit the crack growth in the laser welding process. Sun et al. [25] joined aluminum and titanium by cold metal transfer (CMT) welding process and found that the heating area of weld arc increased and the peak temperature reduced with the adaptation of axial magnetic field. Jin et al. [26] found that the magnetic field can promote the wetting of liquid $\mathrm{Cu}$ on a steel surface and affect the interfacial microstructure evolution in CMT welding process.

Therefore, in the present research, as a welding method characterized by low heat input [27], CMT welding with an external axial magnetic field was adopted to join 6061-T6 aluminum alloy and 304 stainless steel. The purpose of this study is to reveal the effect of the external axial magnetic field on wetting behavior, interfacial microstructure, and mechanical properties.

\section{Materials and Methods}

In this study, 6061-T6 aluminum alloy and 304 stainless steel plates with dimensions of $100 \mathrm{~mm} \times 100 \mathrm{~mm} \times 2 \mathrm{~mm}$ were chosen as base metals. The tensile strength of SS304 and 6061-T6 substrates were $716 \mathrm{MPa}$ and $262 \mathrm{MPa}$, respectively. The filler metal adapted was ER4043 welding wire (Al-5Si wt.\%) with a diameter of $1.2 \mathrm{~mm}$. Table 1 shows the nominal chemical compositions of base metals and filler metal. $\mathrm{V}$ groove with a bevel angle of $45^{\circ}$ was fabricated on the steel side and no groove on the aluminum side.

Table 1. Nominal chemical compositions of base metal and filler metal.

\begin{tabular}{ccccccccccc}
\hline Materials & Al & Fe & Si & Cr & Mn & Ni & Mg & Cu & Ti & C \\
\hline 6061-T6 & Bal. & 0.7 & $0.4-0.8$ & - & 0.15 & - & $08-1.2$ & $0.15-0.4$ & - & 1.0 \\
SS304 & - & Bal. & 1.0 & $18-20$ & 2.0 & $8.0-11$ & - & - & 0.08 & 0.08 \\
ER4043 & Bal. & 0.8 & $4.5-6.0$ & - & 0.3 & - & 0.05 & 0.3 & 0.2 & - \\
\hline
\end{tabular}

The welding process was performed by an industrial robot (ABB, Zurich, Switzerland) and welding source (TPS 4000, Fronius, Pettenbach, Austria) in the normal CMT mode. Figure 1a shows the schematic diagram of the external magnetic field hybrid CMT welding process. The external 
magnetic field was generated through copper coils wound around a hollow iron core. The device was mounted on a welding torch coaxially. The direction of the magnetic field in the welding process was perpendicular to the welded workpiece. The magnetic intensity and alternating frequency can be controlled by the magnitude and frequency of coil current which can operate with control button on the magnetic control power source. Detailed experimental parameters are given in Table 2.
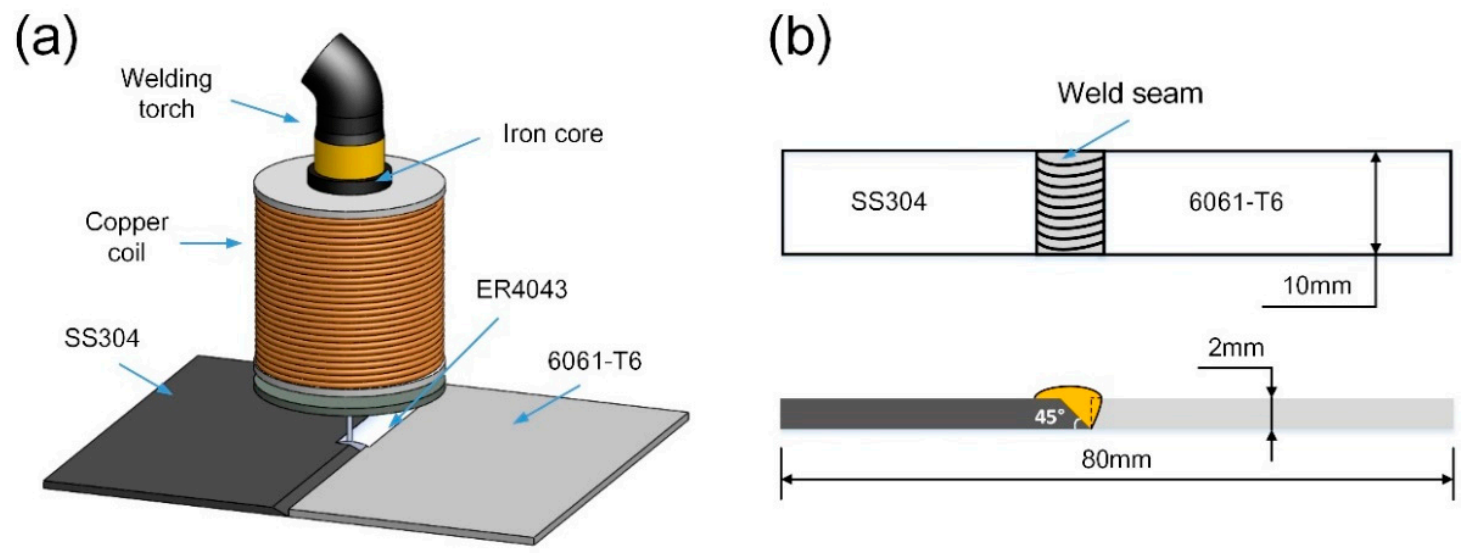

Figure 1. (a) Schematic diagram of the welding device; (b) detailed size of tensile test specimen.

Table 2. Detailed experimental parameters.

\begin{tabular}{cccccc}
\hline $\begin{array}{c}\text { Wire Feeding } \\
\text { Speed (M/Min) }\end{array}$ & $\begin{array}{c}\text { Welding } \\
\text { Current (A) }\end{array}$ & $\begin{array}{c}\text { Welding } \\
\text { Speed (mm/s) }\end{array}$ & Coil Current (A) & $\begin{array}{c}\text { Magnetic } \\
\text { Intensity (mT) }\end{array}$ & $\begin{array}{c}\text { Alternating } \\
\text { Frequency (Hz) }\end{array}$ \\
\hline 4.1 & 73 & 6 & 0 & 0 & 0 \\
4.1 & 73 & 6 & 1 & 6.4 & 0 \\
4.1 & 73 & 6 & 2 & 13.3 & 0 \\
4.1 & 73 & 6 & 3 & 19.5 & 5 \\
4.1 & 73 & 6 & 2 & 13.3 & 10 \\
4.1 & 73 & 6 & 2 & 13.3 & 15 \\
4.1 & 73 & 6 & 2 & 13.3 & \\
\hline
\end{tabular}

To analyze the quality of $\mathrm{Al} /$ steel joint by external magnetic field hybrid CMT welding process, the microstructure of the cross section was observed via scanning electron microscope (SEM, MERLIN Compact, Zeiss, Oberkochen, Germany) equipped with an energy-dispersive X-ray spectrometer (EDS). Transmission electron microscope (TEM, JEOL-2100, JEOL, Tokyo, Japan) was used to characterize the microstructure in detail. Finally, the specimens were cross-sectioned perpendicularly to the welding direction to investigate the mechanical properties of $\mathrm{Al} / \mathrm{steel}$ butt joints, as shown in Figure $1 \mathrm{~b}$. The tensile tests were carried out by a $30 \mathrm{KN}$ universal material testing machine (Instron 5967, Instron, Boston, MA, USA) at a loading rate of $0.5 \mathrm{~mm} / \mathrm{min}$. Three replicates were performed, and the average peak loads were reported to reflect the mechanical properties of the joints. The fractured surfaces of the specimens after tensile testing were examined by SEM with EDS and X-ray diffraction (XRD, DX-2700, Haoyuan, Dandong, China).

\section{Results and Discussion}

\subsection{Weld Appearance}

Figure 2 shows the weld appearances of the $\mathrm{Al} /$ steel butt joints obtained with different magnetic field parameters. Welding current of $73 \mathrm{~A}$ and welding speed of $6 \mathrm{~mm} / \mathrm{s}$ with lower heat input were selected to reduce the formation of brittle Al/Fe IMCs. However, a narrow weld seam was obtained in the normal CMT welding process. The bonding area of aluminum weld metal on the steel surface was smaller. The spreadability improved and the weld width significantly increased with the introduction of the magnetic field. However, the larger welding spatters resulted in the loss of weld 
metal with excessive current of $3 \mathrm{~A}$. The application of alternating frequency can stabilize the welding process and reduce welding spatters effectively, as shown in Figure 2e-g. Furthermore, a wave-like characteristic of weld surface was observed and the waves' spacing was denser with the increase of alternating frequency.
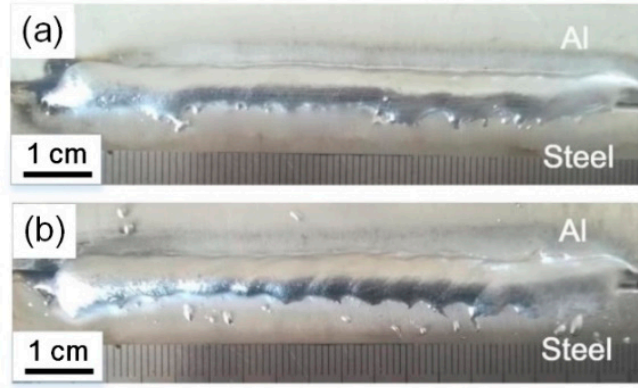

(c)

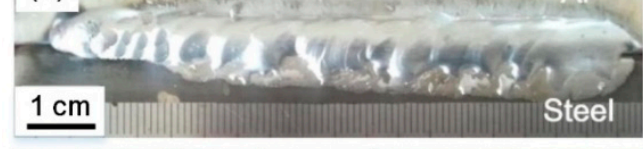

(d)

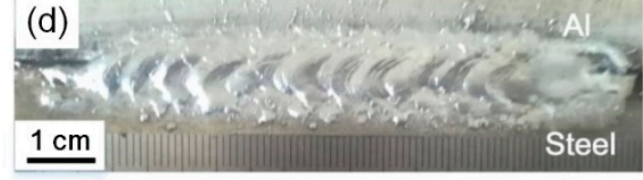

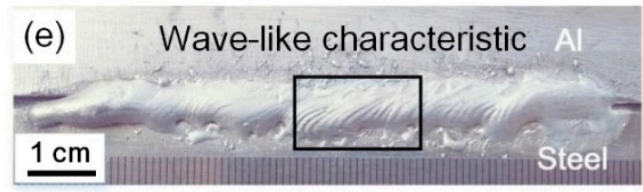
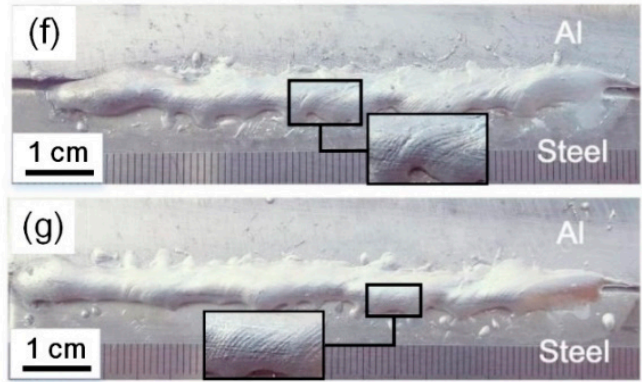

(h)

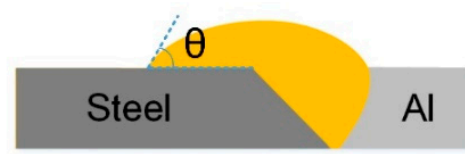

Figure 2. Weld appearances of $\mathrm{Al} /$ steel joints at different magnetic field parameters: (a) $0 \mathrm{~A}, 0 \mathrm{~Hz}$; (b) $1 \mathrm{~A}$, $0 \mathrm{~Hz}$; (c) $2 \mathrm{~A}, 0 \mathrm{~Hz}$; (d) $3 \mathrm{~A}, 0 \mathrm{~Hz}$; (e) $2 \mathrm{~A}, 5 \mathrm{~Hz}$; (f) $2 \mathrm{~A}, 10 \mathrm{~Hz}$; (g) $2 \mathrm{~A}, 15 \mathrm{~Hz}$; (h) schematic diagram of wetting angle $(\theta)$.

In order to quantitatively describe the effect of coil current and alternating frequency on the weld appearance, the wetting angles were measured from the cross sections shown in Figure 3. In the normal CMT process in Figure 3a, the measured wetting angle is $128^{\circ}$, showing the poor wettability of weld metal on the steel surface. With the increase of coil current, the wetting angle tended to decrease with the same heat input. This was related to the arc heating redistribution on steel surface and the forced flowing of molten pool under the action of the external magnetic field. The arc plasma rotated due to the spiral motion of charged particles by the Lorentz force, which resulted in the increase of the arc width. Therefore, the heating area on the surface of the steel plate was expanded [25], which can help to break oxide film and promote wetting of weld metal. Additionally, diverging distribution of current lines existed in the molten pool from top to bottom as well, which was conducive to the spreading behavior of the molten pool driven by the electromagnetic force. Figure $3 \mathrm{~b}$ shows the influence of alternating frequency on the wetting angle when the coil current was fixed at $2 \mathrm{~A}$. The wetting angle increased with alternating frequency because of the weak flow of molten pool. The rotating direction of the arc and molten pool altered under the periodically alternating electromagnetic force. Therefore, the rotation radius of the arc and molten pool decreased due to the inertia force [28], which weakened the spreading dynamic of molten pool. The wave-like feature on the weld surface also indicated that the molten pool had a strong flow behavior before solidification.

\subsection{Interfacial Microstructure}

Figure $4 \mathrm{a}-\mathrm{h}$ shows the interfacial microstructures of $\mathrm{Al} / \mathrm{steel}$ butt joints at different coil currents and the observed position is shown in Figure 4i. It can be seen that an approximate $6 \mu \mathrm{m}$ thick IMC layer was formed at the $\mathrm{Al} / \mathrm{steel}$ interface without the application of the magnetic field. The morphology of the IMC layer became smooth and the average thickness was gradually reduced to $3 \mu \mathrm{m}$ with the increase of coil current, as shown in Figure $4 \mathrm{c}-\mathrm{d}$. This is because the peak temperature of the steel surface was decreased with the expansion effect of arc shape and molten pool, which weakened the 
capacity of element diffusion and suppressed the growth of the IMC layer. However, when the coil current further increased to $3 \mathrm{~A}$, the thickness of IMC layer at the interface became uneven, as seen in Figure 4f. The excessively strong scouring action of rapid flow against steel surface and mass dissolution of Fe can be responsible for this phenomenon.
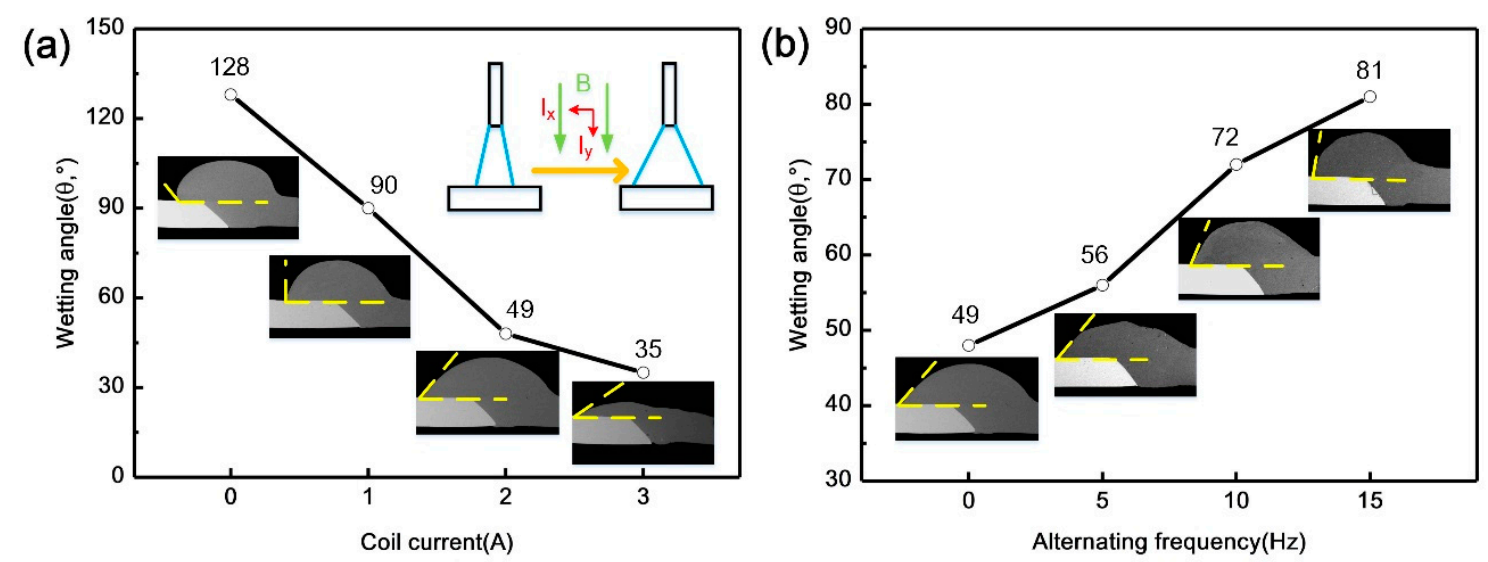

Figure 3. Wetting angle and cross sections of aluminum on steel surface at different magnetic field parameters: (a) Coil current; (b) alternating frequency.
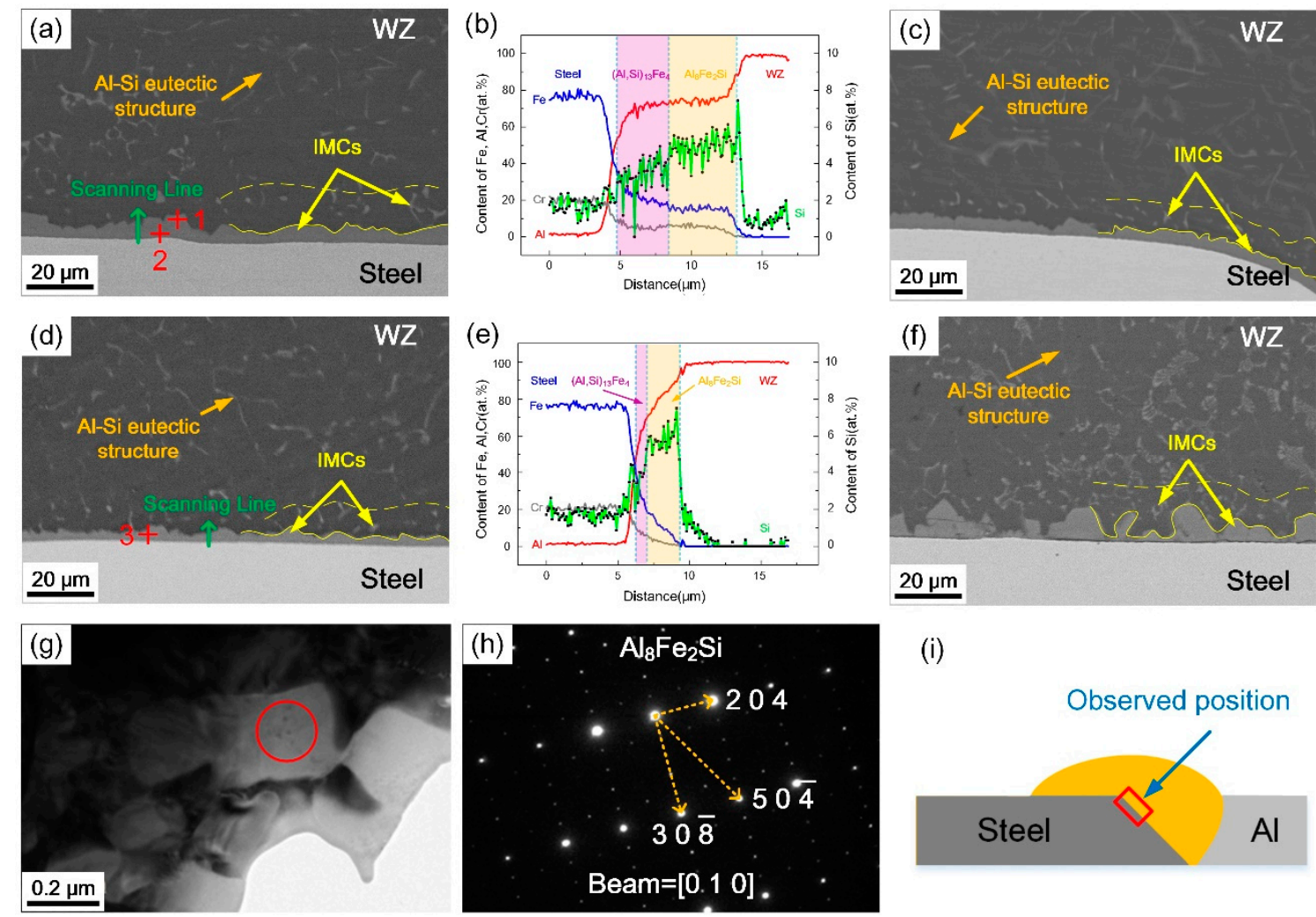

(i)

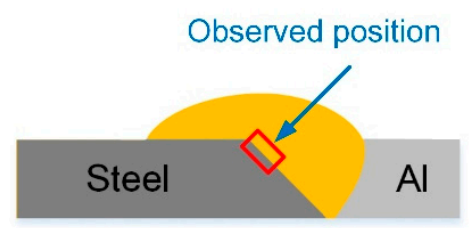

Figure 4. Microstructure, EDS line scanning results and selected area electron diffraction pattern of the WZ)/steel interface at different coil currents: (a,b) 0 A, $0 \mathrm{~Hz}$; (c) 1 A, $0 \mathrm{~Hz}$; (d,e) and (g,h) 2 A, $0 \mathrm{~Hz}$; (f) $3 \mathrm{~A}, 0 \mathrm{~Hz}$; (i) observed position.

According to the EDS results listed in Table 3, the IMC layer obtained from the normal welding process was divided into two layers, including $\left(\mathrm{Al}, \mathrm{Si}_{13} \mathrm{Fe}_{4}\right.$ phase adjacent to steel surface and $\mathrm{Al}_{8} \mathrm{Fe}_{2} \mathrm{Si}$ phase with less $\mathrm{Fe}$ content, which was consistent with the conventional results of $\mathrm{Al} /$ steel fusion welding process with Al-Si filler metal [10-14]. Under the coil current of $2 \mathrm{~A}$, the IMC component was 
mainly $\mathrm{Al}_{8} \mathrm{Fe}_{2} \mathrm{Si}$ with more $\mathrm{Si}$ and less Fe. According to the EDS line scanning results in Figure $4 \mathrm{~b}$,e the thickness of IMC layer reduced and the elemental concentration gradient cross interface was steeper due to the presence of the magnetic field. The $(\mathrm{Al}, \mathrm{Si})_{13} \mathrm{Fe}_{4}$ phase became poor and $\mathrm{Si}$ content increased in the IMC layer. In order to determine the phase of the IMC layer more accurately, TEM micrographs with corresponding SADP taken from the welding zone (WZ)/steel interface are shown in Figure $4 \mathrm{~g}-\mathrm{h}$. The results show that the IMC layer was identified as $\mathrm{Al}_{8} \mathrm{Fe}_{2} \mathrm{Si}$ phase with hexagonal structure.

Table 3. EDS spot scanning results of zones 1-3 in Figure 4.

\begin{tabular}{ccccc}
\hline Location & Al (at.\%) & Si (at.\%) & Fe (at.\%) & Possible Phase \\
\hline 1 & 75.5 & 6.1 & 18.4 & $\mathrm{Al}_{8} \mathrm{Fe}_{2} \mathrm{Si}$ \\
2 & 69.8 & 5.9 & 24.3 & $\left(\mathrm{Al}, \mathrm{Si}_{13} \mathrm{Fe}_{4}\right.$ \\
3 & 72.6 & 8.3 & 19.1 & $\mathrm{Al}_{8} \mathrm{Fe}_{2} \mathrm{Si}$ \\
\hline
\end{tabular}

In addition, changing the alternating frequency of the magnetic field will also affect the interfacial morphology. Figure 5 shows the interfacial microstructures of $\mathrm{Al} /$ steel joints in different alternating frequencies, when the coil current was fixed at $2 \mathrm{~A}$. It was observed that the IMC layer became thicker and uneven with the increase of alternating frequency. Under the action of alternative electromagnetic force and rotating arc, the magnetic frequency intensified the oscillating behavior of molten pool at the front interface, which caused the nonuniform accumulation of local elements and formed a serrated compound layer during rapid cooling. Meanwhile, the rotation radius of weld arc decreased with the alternating magnetic field due to inertia force, which increased the heat input per unit area on the $\mathrm{Al} /$ steel interface, resulting in an increase in the IMC layer thickness [26]. Therefore, the larger the alternating frequency was, the greater the average thickness of the IMC layer became. The corresponding line scanning results show that the thickness of $(\mathrm{Al}, \mathrm{Si})_{13} \mathrm{Fe}_{4}$ layer with lower $\mathrm{Si}$ content increased. However, its proportion was still lower than the normal welding process, indicating that the magnetic field can inhibit the growth of $(\mathrm{Al}, \mathrm{Si})_{13} \mathrm{Fe}_{4}$ layer and promote $\mathrm{Si}$ aggregating at the interface.
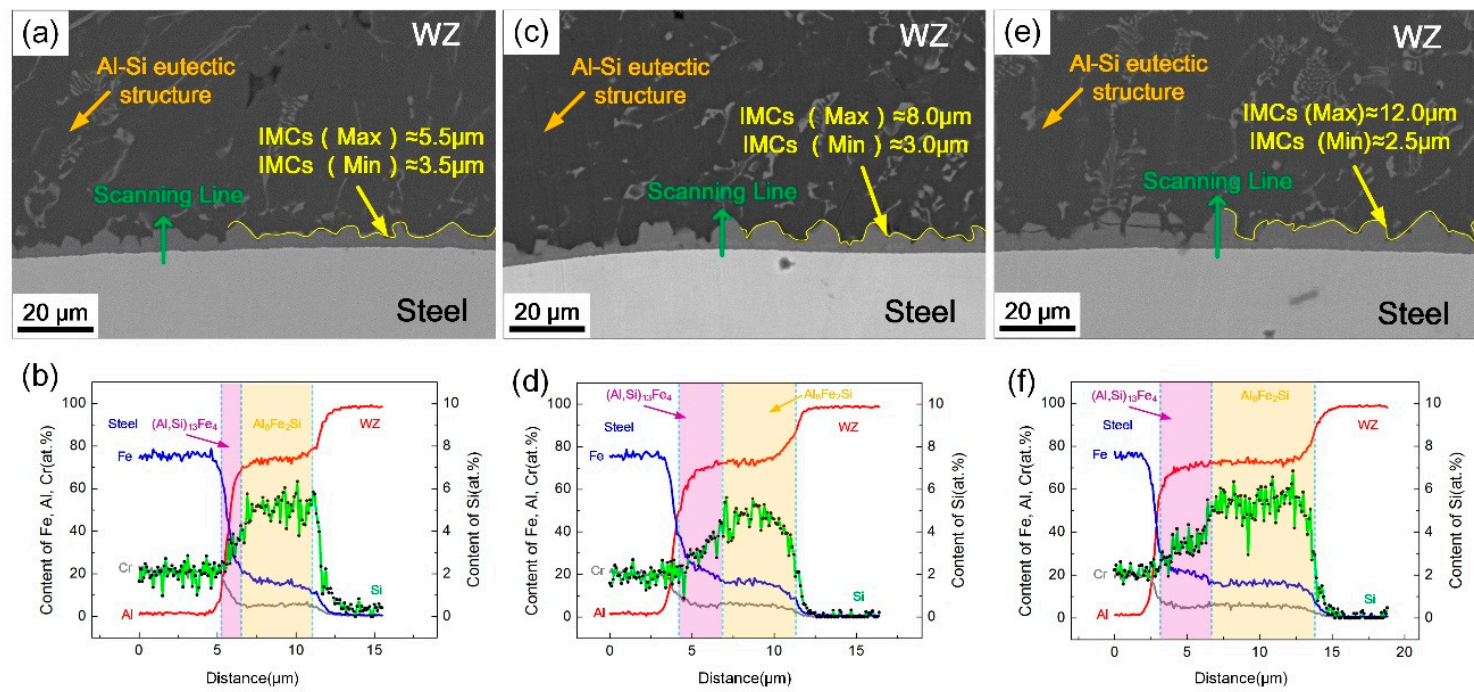

Figure 5. Microstructure and EDS line scanning results of WZ/steel interface at different alternating frequencies: (a,b) $2 \mathrm{~A}, 5 \mathrm{~Hz}$; (c,d) $2 \mathrm{~A}, 10 \mathrm{~Hz}$; (e,f) $2 \mathrm{~A}, 15 \mathrm{~Hz}$.

SEM amplifying images of the IMCs and the distribution of Al, Si and Fe near the interface are presented in Figure 6. For a normal CMT welding process, Si concentrated along the reticulate grain boundary of Al-Si eutectic structure and aggregated at the Al/steel interface where distributed a lower chemical potential. A long-distance diffusion of Fe atoms can be observed at the interface, as well 
as block-shaped distribution in the welding zone, which indicated that Fe had a great capacity for diffusion to aluminum weld.
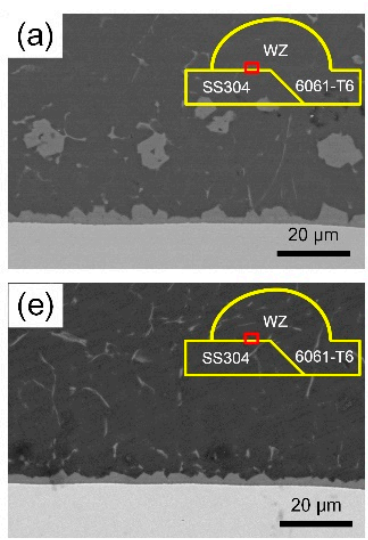
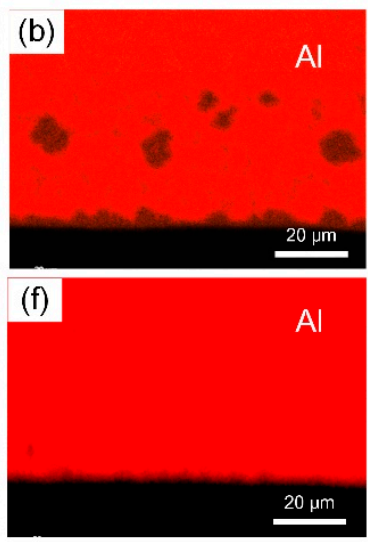
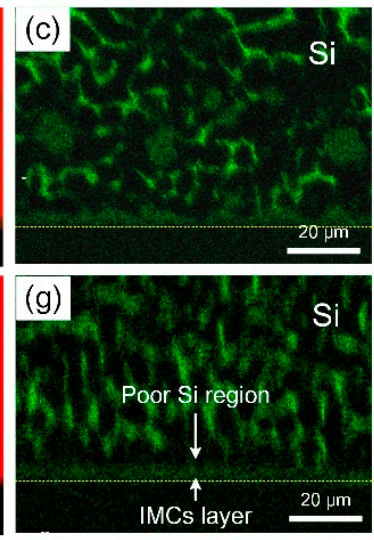
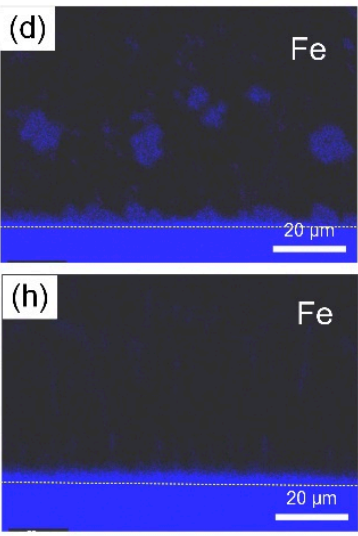

Figure 6. EDS element distribution maps and distribution of $\mathrm{Al}, \mathrm{Si}$ and $\mathrm{Fe}$ in different magnetic field parameters: (a-d) $0 \mathrm{~A}, 0 \mathrm{~Hz}$; (e-h) $2 \mathrm{~A}, 0 \mathrm{~Hz}$.

The thickness of the IMC layer decreased to $3 \mu \mathrm{m}$ and became uniform with the magnetic field. The diffusion of Si was directional toward the steel surface from aluminum weld. Meanwhile, a visible poor Si region occurred near the IMC layer, which can be an evidence of the enrichment effect of $\mathrm{Si}$ under the action of magnetic field as well. This can be attributed to the continuous transportation of $\mathrm{Si}$ atoms to the interface with the rapid flow of molten pool. Conversely, the diffusion degree of Fe was reduced mainly caused by the lower peak temperature. The silicon-rich IMC layer acted as an interdiffusion barrier of $\mathrm{Fe}$ and $\mathrm{Al}$ atoms as well [14].

According to the interfacial reactions [29], the IMC layer formations in the normal CMT process and magnetic field assisted welding were contrastively analyzed to clarify the action mechanism of magnetic field on the interfacial reaction, as presented in Figure 7. In the normal CMT process, the steel dissolved in the molten pool while $\mathrm{Si}$ atoms diffused rapidly and aggregated at the interface. When the temperature fell to $1020^{\circ} \mathrm{C},\left(\mathrm{Al}, \mathrm{Si}_{13} \mathrm{Fe}_{4}\right.$ phase was primarily produced at the interface with $\mathrm{Si}$ atoms substitutional solubilized. $\mathrm{Al}_{8} \mathrm{Fe}_{2} \mathrm{Si}$ phase was formed adjoining to the ( $\left.\mathrm{Al}, \mathrm{Si}\right)_{13} \mathrm{Fe}_{4}$ layer with the reaction of liquid aluminum and $(\mathrm{Al}, \mathrm{Si})_{13} \mathrm{Fe}_{4}$ phase, when the temperature of the interface cooled to $620{ }^{\circ} \mathrm{C}$. The $\mathrm{Al}_{8} \mathrm{Fe}_{2} \mathrm{Si}$ layer grew to $\mathrm{WZ}$, while the $(\mathrm{Al}, \mathrm{Si})_{13} \mathrm{Fe}_{4}$ layer was consumed to a thinner thickness. Finally, Fe and Si atoms far in the weld formed block-shaped or rod-shaped $\mathrm{Al}_{8} \mathrm{Fe}_{2} \mathrm{Si}$ phase with the solidification of aluminum.

With the application of the external axial magnetic field, the diffusion distance of Fe atoms was shortened and more $\mathrm{Si}$ atoms aggregated at the interface. $(\mathrm{Al}, \mathrm{Si})_{13} \mathrm{Fe}_{4}$ layer was generated and grew in the temperature range of $1020-620^{\circ} \mathrm{C}$. However, the production of $(\mathrm{Al}, \mathrm{Si})_{13} \mathrm{Fe}_{4}$ declined on account of the shortening of the residence time at this temperature range. Furthermore, $(\mathrm{Al}, \mathrm{Si})_{13} \mathrm{Fe}_{4}$ layer was constantly smashed by the strong scouring action of rapidly flowing molten pool. The smashed compounds and remaining $(\mathrm{Al}, \mathrm{Si})_{13} \mathrm{Fe}_{4}$ layer reacted with liquid aluminum to form $\mathrm{Al}_{8} \mathrm{Fe}_{2} \mathrm{Si}$ phase, when the interfacial temperature decreased to $620^{\circ} \mathrm{C}$. The $\mathrm{Al}_{8} \mathrm{Fe}_{2} \mathrm{Si}$ layer grew with the consumption of liquid aluminum and remaining $(\mathrm{Al}, \mathrm{Si})_{13} \mathrm{Fe}_{4}$ phase. Hence rare $(\mathrm{Al}, \mathrm{Si})_{13} \mathrm{Fe}_{4}$ remained and the main component of the IMC layer was $\mathrm{Al}_{8} \mathrm{Fe}_{2} \mathrm{Si}$ phase, which had an improvement on mechanical properties.

\subsection{Tensile Strength and Failure Behavior}

Figure 8 shows the tensile strength of the specimens with various magnetic field parameters, which was reported to represent the mechanical properties of the joints. The results show that the tensile strength increased with the rise of coil current, although it dropped when the coil current increased to $3 \mathrm{~A}$. The variation of the tensile strength was positively associated with IMC layer thickness with the increase of coil current. Additionally, the increase of the bonding area can further improve 
the tensile strength. As shown in Figure 8b, the tensile strength decreased with the rise of alternating frequency. The phenomenon can be attributed to the increase of the thickness of the IMC layer and $(\mathrm{Al}, \mathrm{Si})_{13} \mathrm{Fe}_{4}$ phase content formed at higher temperature.
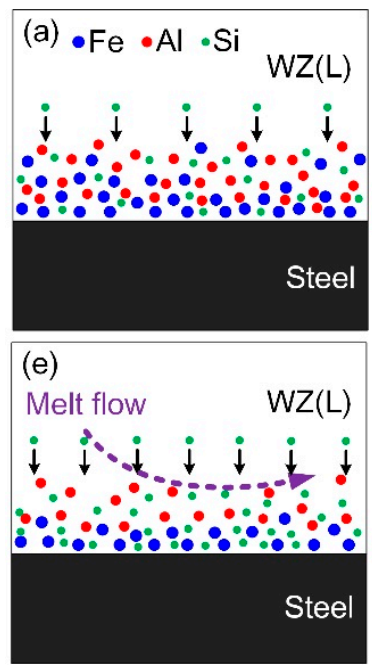

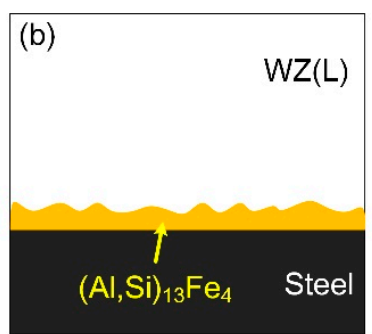

(f)

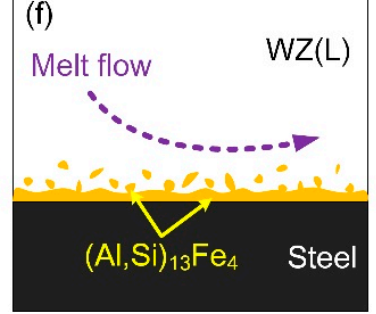

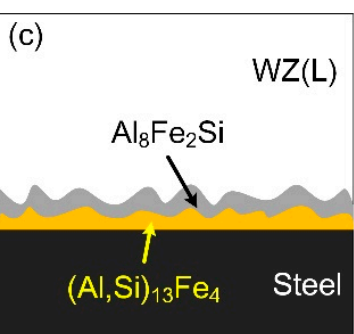

(g)

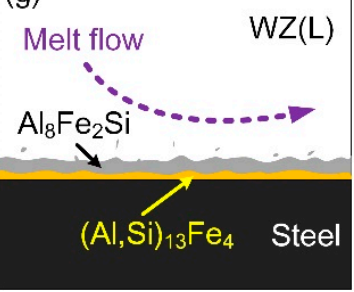

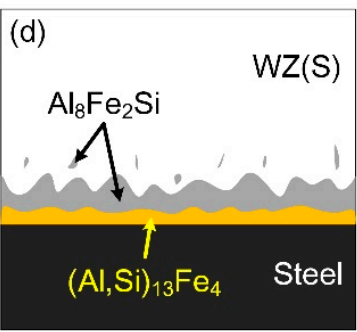

(h)

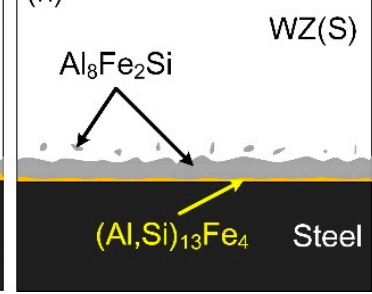

Figure 7. Schematic diagram of IMC layer formation: (a-d) In the normal welding process; (e-h) with axial magnetic field assisted.
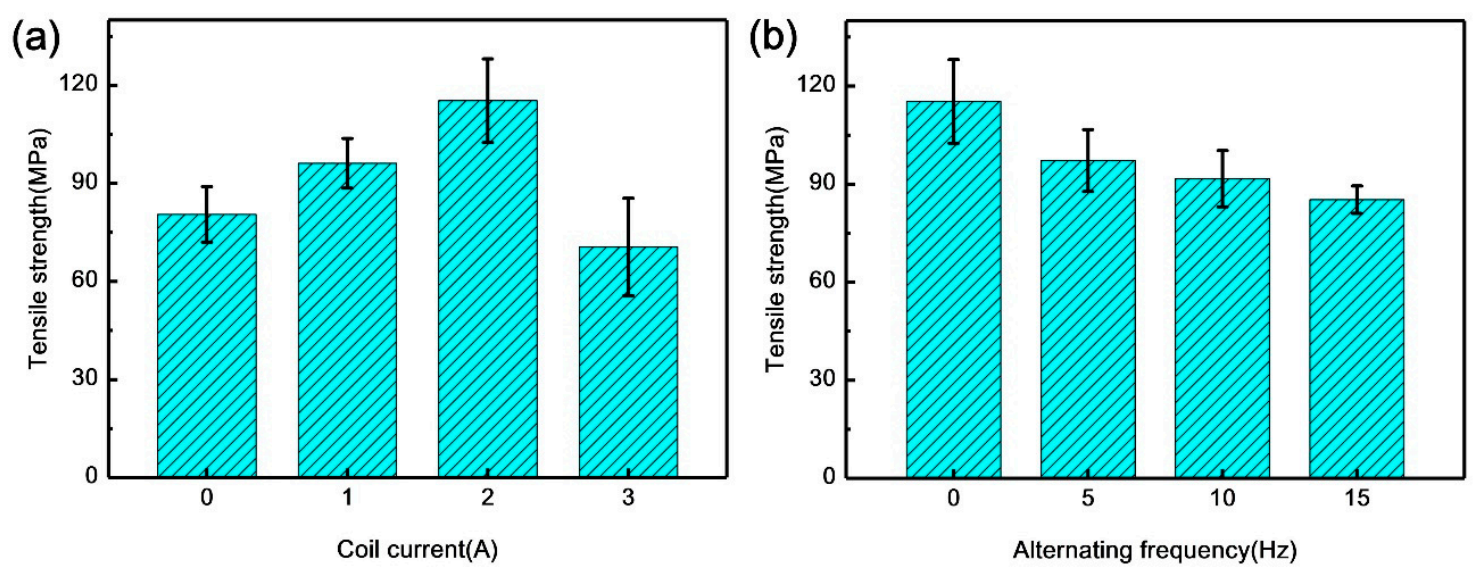

Figure 8. Tensile strength of the specimens with different various field parameters: (a) Coil current; (b) alternating frequency.

Figure 9 shows the fracture path and fractography of the welded joints with various welding conditions. Chemical compositions of location 1-5 obtained by EDS detections are listed in Table 4 . In Figure $9 \mathrm{a}-\mathrm{c}$, the joints fractured along the $(\mathrm{Al}, \mathrm{Si})_{13} \mathrm{Fe}_{4}$ layer without the magnetic field. The joint was characterized by brittle fracture with flat fracture surface and no dimples. The fracture surface was smooth and $(\mathrm{Al}, \mathrm{Si})_{13} \mathrm{Fe}_{4}$ compound was identified. The fracture morphology in region 2 was $\alpha$-Al phase with a content of 98.1 at.\% $\mathrm{Al}$ and 1.9 at.\% Si. In region 3 , rough fracture surface was located on the bottom of the groove where the crack source was. The component was made up of 72.6 at.\% $\mathrm{Al}, 8.3$ at.\% $\mathrm{Si}$ and 19.1 at. \% Fe, implying that this IMC was $\mathrm{Al}_{8} \mathrm{Fe}_{2} \mathrm{Si}$ phase. To further confirm the phase, XRD analysis was performed and the results are shown in Figure $9 \mathrm{~d}$. The results show that $\mathrm{Al}, \mathrm{Al}_{8} \mathrm{Fe}_{2} \mathrm{Si}$ and $\mathrm{Al}_{13} \mathrm{Fe}_{4}$ were found on the fracture surface. 

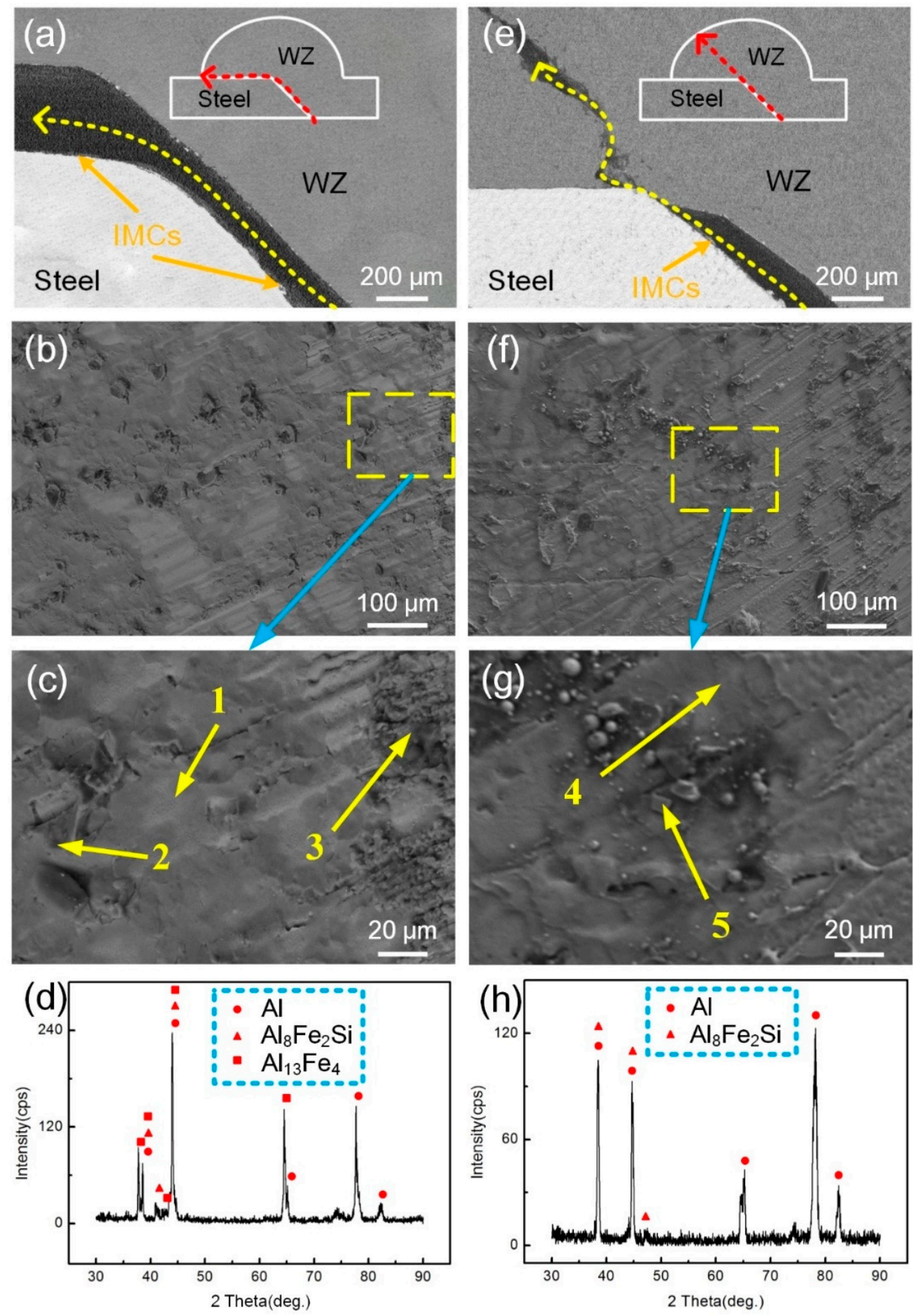

Figure 9. Fracture path, fractography and $\mathrm{XRD}$ analysis results of steel side of tensile specimens with various welding conditions: (a-d) $0 \mathrm{~A}, 0 \mathrm{~Hz}$; (e-h) $2 \mathrm{~A}, 0 \mathrm{~Hz}$.

Table 4. EDS spot scanning results of zones 1-5 in Figure 9.

\begin{tabular}{ccccc}
\hline Location & Al (at.\%) & Si (at.\%) & Fe (at.\%) & Possible Phase \\
\hline 1 & 69.7 & 5.8 & 24.5 & $\left(\mathrm{Al}, \mathrm{Si}_{13} \mathrm{Fe}_{4}\right.$ \\
2 & 98.1 & 1.9 & - & $\alpha-\mathrm{Al}$ solid \\
3 & 72.6 & 8.3 & 19.1 & $\mathrm{Al}_{8} \mathrm{Fe}_{2} \mathrm{Si}$ \\
4 & 74.2 & 8.0 & 17.8 & $\mathrm{Al}_{8} \mathrm{Fe}_{2} \mathrm{Si}$ \\
5 & 92.8 & 7.2 & - & $\alpha-\mathrm{Al} \mathrm{solid}$ \\
\hline
\end{tabular}


In Figure 9e-g, a mixed fracture path including $\mathrm{Al}_{8} \mathrm{Fe}_{2} \mathrm{Si}$ layer and $\mathrm{WZ}$ was obtained with the introduction of the magnetic field. The typical morphology of the fracture surface was composed of $\mathrm{Al}_{8} \mathrm{Fe}_{2} \mathrm{Si}$ phase and $\alpha$-Al flakes that distributed on the $\mathrm{Al}_{8} \mathrm{Fe}_{2} \mathrm{Si}$ IMC layer. The results indicate that the change of the IMC components from $(\mathrm{Al}, \mathrm{Si})_{13} \mathrm{Fe}_{4}$ to $\mathrm{Al}_{8} \mathrm{Fe}_{2} \mathrm{Si}$ phase, effectively improving the tensile strength of the joints. The XRD analysis in Figure $9 \mathrm{~h}$ further verified the existence of these two products.

\section{Conclusions}

In this study, an axial magnetic field was introduced to the CMT butt-welding of 6061 aluminum alloy and 304 stainless steel with ER4043 filler metal. The effects of the external axial magnetic field on weld appearance, interfacial microstructure, and tensile strength of the resultant joints were investigated. The conclusions are summarized as follows:

(1) With the increase of coil current, the spreadability of the molten filler was improved and the wetting angle decreased from to $128^{\circ}$ to $35^{\circ}$. The wetting facilitation effect on the molten pool was reduced with the increase of alternating frequency. The wave-like characteristic occurred on the weld surface after the solidification of the fiercely stirred molten pool.

(2) With the assistance of the magnetic field, the growth of the IMC layer was inhibited and the transformation of the IMC layer from (Al, Si)13Fe4 to Al8Fe2Si phase was promoted, which was beneficial to the mechanical properties of $\mathrm{Al} /$ steel joints. However, excessive coil current and the increase of alternating frequency resulted in a thicker and uneven IMC layer.

(3) The maximum tensile strength reached 130.2 MPa with the coil current and alternating frequency of $2 \mathrm{~A}$ and $0 \mathrm{~Hz}$, increasing by a 61.6\% contrast with the normal CMT welding process. The fracture path changed from the (Al, Si)13Fe4 layer to Al8Fe2Si layer-welding zone.

(4) In future work, the effect of the magnetic field on the dynamic behavior of the molten pool will be investigated by numerical analysis combined with experimental observation.

Author Contributions: Conceptualization, Q.S. and Y.L.; methodology, Y.L.; software, C.L., Z.Z. and Y.W.; validation, K.K., J.L. and Y.L.; formal analysis, Y.L.; investigation, K.K.; resources, Y.L.; data curation, K.K.; writing-original draft preparation, K.K.; writing-review and editing, K.K., J.L. and Y.L.; visualization, K.K.; supervision, Y.L.; project administration, Q.S.; funding acquisition, Q.S. All authors have read and agreed to the published version of the manuscript.

Funding: This project is supported by the National Natural Science Foundation of China (Grant No. 51705103, U1960102, 51475104).

Conflicts of Interest: The authors declare no conflict of interest.

\section{References}

1. Gullino, A.; Matteis, P.; D'Aiuto, F. Review of aluminum-to-steel welding technologies for car-body applications. Metals 2019, 9, 315. [CrossRef]

2. Greenberg, B.A.; Ivanov, M.A.; Pushkin, M.S.; Inozemtsev, A.V.; Patselov, A.M.; Tankeyev, A.P.; Kuzmin, S.V.; Lysak, V.I. Formation of intermetallic compounds during explosive welding. Metall. Mater. Trans. A 2016, 47, 5461-5473. [CrossRef]

3. Bataev, I.A.; Ivanov, I.V.; Malyutina, Y.N.; Émurlaev, K.I.; Émurlaeva, Y.Y. High plastic deformations and high cooling rates at the interface of explosion-welded materials. Met. Sci. Heat. Treat. 2019, 60, 674-679. [CrossRef]

4. Chen, Y.C.; Komazaki, T.; Kim, Y.G.; Tsumura, T.; Nakata, K. Interface microstructure study of friction stir lap joint of AC4C cast aluminum alloy and zinc-coated steel. Mater. Chem. Phys. 2008, 111, 375-380. [CrossRef]

5. Cao, R.; Yu, G.; Chen, J.H.; Wang, P.C. Cold metal transfer joining aluminum alloys-to-galvanized mild steel. J. Mater. Process. Technol. 2013, 213, 1753-1763. [CrossRef]

6. Springer, H.; Szczepaniak, A.; Raabe, D. On the role of zinc on the formation and growth of intermetallic phases during interdiffusion between steel and aluminium alloys. Acta Mater. 2015, 96, 203-211. [CrossRef] 
7. Arghavani, M.R.; Movahedi, M.; Kokabi, A.H. Role of zinc layer in resistance spot welding of aluminium to steel. Mater. Des. 2016, 102, 106-114. [CrossRef]

8. Su, J.H.; Yang, J.; Li, Y.L.; Yu, Z.S.; Chen, J.S.; Zhao, W.Q.; Liu, H.B.; Tan, C.W. Microstructure and mechanical properties of laser fusion welded $\mathrm{Al} /$ steel joints using a Zn-based filler wire. Opt. Laser Technol. 2020, 122, 105882. [CrossRef]

9. He, H.; Lin, S.B.; Yang, C.L.; Fan, C.L.; Chen, Z. Combination effects of nocolok flux with Ni powder on properties and microstructures of aluminum-stainless steel TIG welding-brazing joint. J. Mater. Eng. Perform. 2013, 22, 3315-3323. [CrossRef]

10. Song, J.L.; Lin, S.B.; Yang, C.L.; Fan, C.L. Effects of Si additions on intermetallic compound layer of aluminum-steel TIG welding-brazing joint. J. Alloy. Compd. 2009, 488, 217-222. [CrossRef]

11. Song, J.L.; Lin, S.B.; Yang, C.L.; Fan, C.L.; Ma, G.C. Analysis of intermetallic layer in dissimilar TIG welding-brazing butt joint of aluminium alloy to stainless steel. Sci. Technol. Weld. Join. 2010, 15, 213-218. [CrossRef]

12. Springer, H.; Kostka, A.; Payton, E.J.; Raabe, D.; Kaysser-Pyzalla, A.; Eggeler, G. On the formation and growth of intermetallic phases during interdiffusion between low-carbon steel and aluminum alloys. Acta Mater. 2011, 59, 1586-1600. [CrossRef]

13. Yang, J.; Yu, Z.S.; Li, Y.L.; Zhang, H.; Guo, W.; Zhou, N. Influence of alloy elements on microstructure and mechanical properties of Al/steel dissimilar joint by laser welding/brazing. Weld. World 2018, 62, 427-433. [CrossRef]

14. Xia, H.B.; Zhao, X.Y.; Tan, C.W.; Chen, B.; Song, X.G.; Li, L.Q. Effect of Si content on the interfacial reactions in laser welded-brazed Al/steel dissimilar butted joint. J. Mater. Process. Technol. 2018, 258, 9-21. [CrossRef]

15. Wachowski, M.; Kosturek, R.; Śniezek, L.; Sebastian, M.; Stefanik, A.; Szota, P. The effect of post-weld hot-rolling on the properties of explosively welded Mg/Al/Ti multilayer composite. Materials 2020, 13, 1930. [CrossRef]

16. Shiran, M.K.G.; Khalaj, G.; Pouraliakbar, H.; Jandaghi, M.R.; Dehnavi, A.S.; Bakhtiari, H. Multilayer Cu/Al/Cu explosive welded joints: Characterizing heat treatment effect on the interface microstructure and mechanical properties. J. Manuf. Process. 2018, 35, 657-663. [CrossRef]

17. Shiran, M.K.G.; Khalaj, G.; Pouraliakbar, H.; Jandaghi, M.; Bakhtiari, H.; Shirazi, M. Effects of heat treatment on the intermetallic compounds and mechanical properties of the stainless steel 321-aluminum 1230 explosive-welding interface. Int. J. Miner. Met. Mater. 2017, 24, 1267-1277. [CrossRef]

18. Li, L.Q.; Xia, H.B.; Tan, C.W.; Ma, N.S. Influence of laser power on interfacial microstructure and mechanical properties of laser welded-brazed Al/steel dissimilar butted joint. J. Manuf. Process. 2018, 32, 160-174. [CrossRef]

19. Sun, J.H.; Yan, Q.; Gao, W.; Huang, J. Investigation of laser welding on butt joints of Al/steel dissimilar materials. Mater. Des. 2015, 83, 120-128. [CrossRef]

20. Yuan, R.; Deng, S.J.; Cui, H.C.; Chen, Y.X.; Lu, F.G. Interface characterization and mechanical properties of dual beam laser welding-brazing Al/steel dissimilar metals. J. Manuf. Process. 2019, 40, 37-45. [CrossRef]

21. Mathieu, A.; Rajashekar, S.; Deschamps, A.; Suery, M.; Matte, S.; Grevey, D.; Cicala, E. Dissimilar material joining using laser (aluminum to steel using zinc-based filler wire). Opt. Laser Technol. 2007, 39, 652-661. [CrossRef]

22. Sun, J.H.; Yan, Q.; Li, Z.G.; Huang, J. Effect of bevel angle on microstructure and mechanical property of $\mathrm{Al} /$ steel butt joint using laser welding-brazing method. Mater. Des. 2016, 90, 468-477. [CrossRef]

23. Chen, R.; Jiang, P.; Shao, X.Y.; Mi, G.Y.; Wang, C.M. Effect of magnetic field on crystallographic orientation for stainless steel 316L laser-MIG hybrid welds and its strengthening mechanism on fatigue resistance. Int. J. Fatigue 2018, 112, 308-317. [CrossRef]

24. Yan, F.; Wang, X.W.; Chai, F.; Ma, H.J.; Tian, L.L.; Du, X.Z.; Wang, C.M.; Wang, W. Improvement of microstructure and performance for steel/Al welds produced by magnetic field assisted laser welding. Opt. Laser Technol. 2019, 113, 164-170. [CrossRef]

25. Sun, Q.J.; Li, J.Z.; Liu, Y.B.; Jiang, Y.L.; Kang, K.X.; Feng, J.C. Arc characteristics and droplet transfer process in CMT welding with a magnetic field. J. Manuf. Process. 2018, 32, 48-56. [CrossRef]

26. Jin, P.; Liu, Y.B.; Sun, Q.J.; Li, J.Z.; Chen, K.; Hou, S.J.; Yang, H.; Zhou, Y.H.; Feng, J.C. Wetting mechanism and microstructure evolution of TC4/304 stainless steel joined by CMT with an assisted hybrid magnetic field. J. Alloy. Compd. 2020, 819, 152951. [CrossRef] 
27. Wang, L.W.; Suo, Y.C.; Wu, C.F.; Wang, D.L.; Liang, Z.M. Effect of pulse frequency on microstructure and mechanical properties of $2198 \mathrm{Al}-\mathrm{Li}$ alloy joints obtained by ultrahigh-frequency pulse AC CMT welding. Materials 2019, 12, 79. [CrossRef]

28. Sun, Q.J.; Li, J.Z.; Liu, Y.B.; Li, B.P.; Xu, P.W.; Feng, J.C. Microstructural characterization and mechanical properties of $\mathrm{Al} / \mathrm{Ti}$ joint welded by CMT method-Assisted hybrid magnetic field. Mater. Des. 2017, 116, 316-324. [CrossRef]

29. Gupta, S.P. Intermetallic compound formation in Fe-Al-Si ternary system: Part I. Mater. Charact. 2003, 46, 269-291. [CrossRef]

(C) 2020 by the authors. Licensee MDPI, Basel, Switzerland. This article is an open access article distributed under the terms and conditions of the Creative Commons Attribution (CC BY) license (http://creativecommons.org/licenses/by/4.0/). 